\title{
Yesus Sang Imanuel sebagai Pembebas: Pencarian Gagasan Pembebasan dalam Injil Matius dan Implikasinya bagi Gereja di Indonesia
}

\author{
Noel Ghota Prima Bayu Surbakti \\ Sekolah Tinggi Teologi Sriwijaya \\ noelsurbakti1993@gmail.com
}

\begin{abstract}
Liberation Theology once a new hope for the Third World theology. Not only for its efforts to "liberate" Third World theology from domination of West Theology, but also for its concerns of social prolems in society. Lately, there many critics come from scholars which addressed to Liberation Theology. They declared that Liberation Theology was nurtured from wrong biblical interpretation. I see that statement not completely true. Because of that, I will observe the bible to find a liberation theme in the bible. Therefore, the purpose of this paper is to find liberation theme in the bible especially in Gospel of Matthew. For that, I will interpret several texts of Matthew which related to Jesus Emmanuel which become special characteristic in Gospel of Matthew. In my work, I will combine literer analysis with context historism of the first reader from Matthew (Matthean Community). It will find that Gospel of Matthew speak about liberation theme which presented by Jesus Emmanuel. Finally, liberation theme which Liberation Theology speak out actually have a biblical foundation. As its implication, churches in Indonesia also play a role as liberator because Jesus as head of churches is a liberator.
\end{abstract}

Key words: liberation theology, Gospel of Matthew, Jesus Emmanuel

Abstrak: Teologi Pembebasan merupakan sebuah harapan baru dalam berteologi di Dunia Ketiga. Bukan hanya karena upayanya "membebaskan diri" dari pengaruh teologi Barat, tetapi juga karena upayanya dalam memperhatikan permasalahan sosial dalam masyarakat. Tetapi belakangan ini, para ahli mengkritik Teologi Pembebasan. Beberapa ahli menyatakan bahwa Teologi Pembebasan berasal dari penafsiran Alkitab yang salah. Penulis melihat pendapat tersebut tidak sepenuhnya benar. Karena itu penulis berupaya menemukan gagasan pembebasan di dalam Alkitab khususnya dalam Injil Matius. Untuk itu, penulis akan menafsirkan beberapa unit teks dalam Injil Matius yang berkaitan dengan sosok Yesus sang Imanuel yang begitu ditonjolkan dalam Injil Matius. Penafsiran tersebut memperhatikan analisis literer dan konteks historis pembaca pertama Injil Matius (komunitas Matius). Melalui kajian tersebut ditemukan bahwa Injil Matius memuat gagasan pembebasan yang diwujudkan melalui Yesus sang Imanuel. Dengan demikian gagasan pembebasan yang diusung dalam Teologi Pembebasan sesungguhnya memiliki landasan alkitabiah. Sebagai implikasinya, gereja-gereja di Indonesia juga berperan sebagai "pembebas" karena Yesus sebagai kepala gereja merupakan sosok "pembebas."

Kata kunci: teologi pembebasan, Injil Matius, Yesus sang Imanuel

Article History

\begin{tabular}{|l|l|l} 
Submitted: 26 November 2021 & Revised: 3 Februari 2022 & Accepted: 4 Februari 2022
\end{tabular}

\section{PENDAHULUAN}

Sudah menjadi kesepakatan umum bahwa teologi kekristenan modern dipengaruhi oleh corak berteologi Barat. Hal tersebut dikonfirmasi oleh Fernando Segovia yang menyatakan "modern Christian Theology, I argued, was a theology that emanated from the center, grounded as it was in Western civilization" (Segovia, 2006). Corak teologi Barat tersebut memengaruhi corak berteologi di Asia, Amerika Latin, Afrika dan negara-negara Dunia Ketiga lainnya yang notabene merupakan hasil 
penginjilan dari misionaris Barat. Di tengah pengaruh kuat teologi barat tersebut pernah hadir sebuah pergerakan teologi yang dikenal sebagai Teologi Pembebasan. R.S. Sugirtharajah melihat bahwa Teologi Pembebasan merupakan sebuah harapan baru berteologi dalam Dunia Ketiga di tengah pengaruh teologi Barat (Sugirtharajah, 2001).

Teologi Pembebasan merupakan sebuah gerakan yang muncul dalam lingkungan Gereja Katolik di Amerika Latin sekitar tahun 1950 - 1960an. Teologi Pembebasan lahir sebagai respons atas realitas ketidakadilan yang dialami oleh orang-orang miskin. Hal tersebut terlihat dari pernyataan Boof bersaudara, "Liberation Theology was born when faith confronted the injustice done to the poor" (Boof \& Boof, 1987). Namun orang miskin yang dimaksud bukan bersifat individual melainkan secara kolektif sebagaimana pernyataan Boof bersaudara, “By 'poor' we do not really mean the poor individual who knocks on the door asking for alms. We mean a collective poor. The 'popular classes': the poor are also the workers exploited by the capitalist system; the under-employed, those pushed aside by the production process" (Boof \& Boof, 1987). Pada awalnya Teologi Pembebasan sering diidentikkan dengan ketidakadilan dan kemiskinan terkhusus di Amerika Latin. Tetapi seiring perkembangannya, negaranegara lain di Dunia Ketiga juga mengikuti pergerakan teologi pembebasan tersebut. Dengan demikian perhatian teologi pembebasan tidak hanya tertuju pada ketidakadilan dan kemiskinan yang terjadi di Amerika Latin melainkan kepada orangorang yang mengalami penindasan (the others) di tempat lain. Oleh karena itu penulis juga setuju dengan Sugirtharajah bahwa Teologi Pembebasan merupakan harapan baru berteologi dalam Dunia Ketiga. Bukan hanya karena ia mencoba "melepaskan diri" dari dominasi teologi Barat, tetapi juga karena semangat Teologi Pembebasan yang peduli terhadap isu-isu praktis dalam masyarakat seperti penindasan, ketidakadilan, kemiskinan dan sebagainya. Sehingga melalui Teologi Pembebasan tersebut gereja diajak untuk berpartisipasi dalam permasalahan sosial yang dihadapi oleh masyarakat dan berupata untuk "membebaskannya."

Tetapi tidak semua ahli memberikan pandangan positif terhadap Teologi Pembebasan. Banyak ahli mengkritik Teologi Pembebasan khususnya berkaitan dengan metode penafsiran yang diterapkan dalam Teologi Pembebasan. Metode penafsiran dalam Teologi Pembebasan sendiri memang mengalami perkembangan dari waktu ke waktu. Pada dasarnya, metode penafsiran dalam teologi pembebasan yakni dengan membaca/menafsirkan Alkitab dari sudut pandang orang-orang tertindas (Boof \& Boof, 1987). Pola tersebut sering disebut dengan istilah hermeneutical circle 
yang diperkenalkan oleh Juan Luis Segundo. Hermeneutical circle beranjak dari analisis terhadap realitas kehidupan sehari-hari dari sebuah konteks dengan segala permasalahan dan konfliknya, kemudian bergerak menuju teks Alkitab untuk melihat pesannya, lalu kembali ke dalam konteks dengan membawa pesan dari teks Alkitab untuk menjawab permasalahan konteks. Namun Sugirtharajah menggambarkan ada tiga tahap perkembangan hermeneutika pembebasan (Sugirtharajah, 2001). Tahap pertama ia sebut dengan istilah classical liberation hermeneutics (hermeneutika pembebasan klasik) yang berkenaan dengan model hermeneutical circle sebagaimana telah dijelaskan sebelumnya (Sugirtharajah, 2001). Tahap perkembangan kedua disebut dengan istilah Peoples' Reading (pembacaan orangorang). Dalam tahap kedua tersebut, orang-orang dalam komunitas Kristen awam yang bukan kalangan teolog bebas untuk menafsirkan Alkitab (Sugirtharajah, 2001). Tahap ketiga disebut dengan istilah identity-specific reading. Dalam tahap ketiga tersebut, orang-orang minoritas seperti orang pribumi, perempuan dan orang-orang yang menjadi korban dari kekuatan internal maupun eksternal bebas untuk membaca Alkitab dalam rangka pembacaan pembebasan (Sugirtharajah, 2001). Berdasarkan penggambaran tersebut, dapat dilihat bahwa metode penafsiran teologi pembebasan bergerak kepada sebuah kebebasan dalam menafsirkan Alkitab. Hal ini senada dengan pernyataan Andrei Meleshko. Setelah menampilkan beberapa metode yang diusulkan oleh para teolog pembebasan, Meleshko menyatakan,

"Thereby, we can see that method of free association, as well as the allegorical method and the method called reader response, are quite widespread among believers in the Base Communities [of liberation theology] and is accepted by them as the most suitable for their situation." (Meleshko, 2013)

Tidak hanya bebas menafsirkan teks, bahkan terlihat adanya penolakan yang dilakukan oleh pengikut teologi pembebasan untuk melakukan eksegese terhadap Alkitab. Hal tersebut kembali terlihat dari pernyataan Meleshko yang menyatakan, "the way interpretation, usually used by followers of the Theology of Liberation, both the theologians as well as ordinary belivers, refuses exegesis and [but?] applies a Bible text directly to a contemporary situation, to people's life and needs (Meleshko, 2013). Meleshko melanjutkan, the hermeneutic which prefers to discover the historical meaning of Bible text, meaning of "then and there" but not "here and now", is, for them [followers of the Theology of Liberation], a 'hellish' hermeneutic" (Meleshko, 2013). Berdasarkan pernyataan tersebut terlihat bahwa para pengikut teologi pembebasan memang enggan untuk melakukan eksegese terhadap Alkitab bahkan mereka 
menganggap upaya untuk melihat makna teks Alkitab dalam konteks historisnya merupakan suatu hal yang "kejam." Karena itu sangat wajar jika banyak kritik yang ditujukan kepada teologi pembebasan. Salah satunya Meleshko sendiri yang menyatakan, misusing and/or rejecting exegesis can bring one to a wrong interpretation. Ada pula Natalie yang juga mengkritik teologi pembebasan dengan menyatakan, "dasar Alkitab yang menjadi patokan bagi mereka, jelas tidak ditafsirkan secara benar (out of context) ... Jikalau titik berangkat dari teologi seseorang sudah salah, maka seluruh penguraiannya juga salah" (Natalie, 2000). Penelitian yang cukup mutakhir adalah artikel Zoltan Vegel yang berjudul "Liberation Theology: A Critical Analysis." Dalam tulisan tersebut Vegel mengkritik teologi pembebasan dengan menafsirkan kembali beberapa pokok teologi yang digunakan para pengikut teologi pembebasan, salah satunya mengenai Yesus sebagai pembebas (Vogel, 2018). Sebagai kalimat kesimpulan Vegel menyatakan, "Jesus didn't come to be a social reformer" (Vogel, 2018).

Berdasarkan pemaparan di atas kita dapat melihat titik tolak kritik terhadap teologi pembebasan dikarenakan adanya penafsiran yang mengedepankan kebebasan dalam menafsirkan teks - reader response atau context to text. Karena itu banyak kritikus yang menganggap teologi pembebasan tidak lahir dari sebuah penafsiran/eksegese Alkitab yang benar. Namun kritik tersebut tidak sepenuhnya benar. Bagi penulis, Teologi Pembebasan memiliki sebuah landasan biblika di mana Yesus sendiri merupakan sosok pembebas. Oleh karena itu penulis hendak menggali gagasan pembebasan dalam Alkitab dengan tetap setia kepada teks Alkitab. Jika ada teolog pembebasan yang enggan atau secara bebas menafsir Alkitab itu soal lain. Tetapi dalam hal ini penulis akan menggali gagasan pembebasan dengan "setia" kepada teks.

Dalam tulisan ini penulis akan melihat gagasan pembebasan dalam Injil Matius yang dinyatakan dalam diri Yesus. Adapun alasan pemilihan Injil Matius dikarenakan gagasan pembebasan sangat erat pada Yesus sang Imanuel yang disajikan oleh Injil Matius. Dalam tulisan ini penulis akan menyajikan gagasan pembebasan dalam Injil Matius dari sisi literer. Setelah itu penulis akan melihat konteks historis teks tersebut atau lebih tepatnya konteks pembaca pertama Injil Matius yang disebut sebagai Komunitas Matius. J.H. Elliot menyatakan, "text both as reflection of and a response to the social and cultural setting in which the text was produced" (Elliot, 1995). Beranjak dari pernyataan tersebut maka teks dan konteks pembacanya memiliki kaitan yang sangat erat. Dengan demikian upaya untuk menyajikan sisi teks dan konteks pembaca 
pertamanya bertujuan untuk memperkuat bahwa makna yang dihasilkan dalam kajian ini merupakan makna yang hendak disampaikan oleh penulis Injil Matius, bukannya sebuah reader response belaka.

\section{METODE}

Dalam penelitian ini penulis berupaya menemukan gagasan "Pembebasan" dalam Injil Matius. Topik tersebut sesungguhnya berkaitan dengan Teologi Pembebasan. Namun dalam penelitian ini penulis memfokuskan pada pendekatan Biblika dalam menarik gagasan "Pembebasan" dalam Injil Matius. Adapun pendekatan yang akan penulis gunakan yakni analisis literer dan menganalisis konteks historis pembaca pertama Injil Matius.

\section{HASIL DAN PEMBAHASAN}

\section{Yesus Sang Imanuel Sebagai Pembebas}

\section{Analisis Literer: Yesus sang Imanuel}

Dari sisi teks, para ahli menyimpulkan bahwa Injil Matius dibingkai oleh Matius 1:23 dan 28:20 yang merupakan sebuah inklusio. ${ }^{1}$ Kupp memperlihatkan sejumlah tulisan para ahli yang menyimpulkan bahwa Matius 1:23 dan 28:20 merupakan sebuah inklusio (Kupp, 1996). Misalnya R. T. Frace dikutip oleh Kupp menyatakan: "This highest level of Matthew's Christology is effectively summed up in two verses (1:23; 28:20) which are often regarded as a 'framework' around the Gospel' (Kupp, 1996). Realitas inklusio ini membawa para ahli kepada sebuah kesimpulan bahwa "Allah Beserta Kita" merupakan tema utama yang membingkai Injil Matius. Misalnya komentar Luz terhadap Matius 1:23 yang diterjemahkan Kupp: “... Above all, however, Matthew has created an inclusion trough the last verse of his gospel (...28:20), which marks a fundamental theme: The presence of the exalted Lord with his community proves him to be Immanuel, God with us" (Kupp, 1996). Bahkan lebih jauh dari sekedar inklusio di atas, Kupp telah membuktikan bahwa tema "Allah Beserta Kita" memang menjiwai seluruh retorika Injil pertama ini. Hal tersebut terlihat dari thesis statement-nya yang menyatakan:

Certainly the major 'presence' texts - 1:23; 18:20 and 28:20 - have been the focus of attention before. But what weight do these passages carry within the whole story of Matthew? Are there other elements that support this motif? Rarely

${ }^{1}$ Inklusio adalah sebuah teknik literer berupa pengulangan kata atau frasa atau gagasan. Pengulangan ini berperan untuk membingkai sebuah unit teks dengan suatu tema. 
has an interpreter assessed Matthew's presence motif as an element within the full narrative and redactional fabric of the Gospel (Kupp, 1996)

Berdasarkan thesis statement-nya, Kupp tidak hanya meyakini bahwa tema "Allah Beserta Kita" hanya menjadi bingkai luar Injil ini (1:23 dan 28:20) tetapi muncul dan merembesi seluruh narasi dan pengajaran dalam Injil Matius.

Dari tema utama tersebut tampak potret "wajah" Yesus yang disajikan dalam Injil Matius. Sejak awal penulis Injil Matius menyajikan bahwa Yesus adalah Imanuel (Matius 1:23) yang berarti Allah beserta kita. Namun di samping itu, ada atribut lain yang disajikan penulis Matius kepada Yesus sang Imanuel. Tentu saja penyajian tersebut untuk semakin memperkuat potret Yesus sebagai Imanuel (Allah Beserta Kita) yang berkaitan dengan gagasan pembebasan.

\section{Yesus sang Imanuel - Orang Nazaret}

Dalam Matius 2:23 Yesus disajikan sebagai orang Nazaret (Matius 2:23). Jika diperhatikan, pemberian atribut tersebut dalam Injil Matius berbeda dengan penyajian yang diberikan oleh Injil Sinoptik lainnya. Dalam Matius 2:23 dikatakan, "Setibanya di sana ia pun tinggal di sebuah kota yang bernama Nazaret. Hal itu terjadi supaya genaplah firman yang disampaikan oleh nabi-nabi, bahwa la akan disebut: Orang Nazaret." Pemberian atribut secara unik kepada Yesus dalam Injil Matius tentu memiliki makna yang penting untuk digali. Nazaret bukanlah kota yang penting pada masa Yesus di mana penduduknya hanya sekitar 500 orang (Browning, 2011). Letaknya yang agak terpencil dan penduduknya yang memperlihatkan sifat tertentu sebagai orang Yahudi udik dan totok menyebabkan orang Nazaret dipandang rendah. Nazaret hanyalah sebuah kota yang terabaikan dan berisi penduduk miskin dengan berbagai krisis yang menerpa mereka. Dengan demikian, sebagaimana disimpulkan oleh Pelita Surbakti, atribut "Orang Nazaret” yang diberikan penulis Injil Matius hendak menegaskan bahwa Yesus sang Imanuel sangat memahami pergumulan para pembaca-Nya karena Dia juga mengalami apa yang mereka alami (Surbakti, 2017). Sebagai sosok pembebas, Yesus terlebih dahulu memahami dan merasakan pergumulan yang dihadapi penduduk miskin dengan berbagai krisis sebab ia juga berasal dari tempat yang sama dengan mereka.

\section{Yesus sang Imanuel - Hamba Allah}

Dalam Matius 12:18-20 Yesus sang Imanuel digambarkan sebagai Hamba Allah (bdk. Ayat 18). Luz mengatakan bahwa penyajian atribut Hamba tersebut merupakan 
upaya penginjil Matius untuk menyajikan dimensi horizontal (kemanusiaan) Yesus bagi dimensi vertikal yang telah disajikan yakni sebagai Anak Allah (Luz, 1995). Richard Beaton juga memperlihatkan bahwa kutipan atribut tersebut untuk menonjolkan sisi horizontal Yesus (Beaton, 2002). Tetapi yang disayangkan bahwa potret Yesus yang ilahi (vertikal) justru lebih sering digali dan tonjolkan dari pada sosok Yesus yang manusiawi (horizontal) (Beaton, 2002). Hal tersebut terlihat dari kalimat Carter yang mengatakan "J.D. Kingsbury's advocacy of 'Son of God' as the 'central Christological title' in Matthew has been especially prominent" (Carter, 2011). Padahal Yesus sebagai Anak Allah ini muncul dalam ketiga kitab Injil kanonik yang lain, namun atribut Yesus sebagai Hamba Allah tidak muncul dalam Injil kanonik yang lain. Karena itu potret Yesus sang Imanuel sebagai Hamba akan digali dan kita tonjolkan.

Potret Yesus Matius yang termuat dalam Mat. 12:18-20 adalah sebagai Hamba Allah. Ini merupakan kutipan dari Yesaya 42:1-4. Pada umumnya pengutipan nubuatan dalam PL memiliki tujuan untuk menegaskan bahwa Yesus yang sedang diberitakan oleh penginjil Matius ini adalah Yesus yang telah dinubuatkan dalam Kitab Suci (Hebrew Bible). Tetapi dalam bagian ini, dari sisi naratif dan teologis penyajian atribut ini merupakan semacam upaya penginjil Matius untuk memberikan landasan biblis (biblical base) bahwa Yesus adalah Hamba Allah yang taat kepada kehendak Bapa-Nya dan peduli kepada sekeliling-Nya. Kepedulian kepada sekeliling tersebut cukup beralasan jika mempertimbangkan ungkapan Luz dan Beaton bahwa penyajian atribut Hamba adalah upaya untuk menonjolkan dimensi horizontal (kemanusiaan) Yesus. Kemudian dalam ayat 18b dan 21 muncul gagasan bahwa misi Hamba tersebut berorientasi kepada bangsa-bangsa atau dengan kata lain, hamba tersebut berwawasan universal (antara lain bisa terlihat dalam Mat. 1:3,5,6; 5:45; 24:14; 28:1920). Bila kita bicara tentang bangsa lain (ethnos), tentu tidak hanya berbicara secara geografis. Saldarini mengatakan "The word ethnos has a variety of meaning in Greek. In Homer ethnos may mean a number of people living together,...After Homer ethnos acquired the common meaning "people" and "nation," referring to a group of people with cultural, linguistic, geographical, or political unity" (Saldarini, 2001). Artinya kata ethnos bisa pula dalam arti non geografis seperti: suku, budaya, latar belakang sosial, latar belakang ekonomi, dll. Atau bisa pula keduanya yakni geografis dan nongeografis. Jadi orientasi misi Yesus sang Imanuel sebagai Hamba bersifat sangat universal dan meyentuh semua aspek kehidupan. Karena itu Beaton dengan mengutip Gerhardsson menyebut multi-faceted Christology (Beaton, 2002). Melalui kalimat "Buluh yang patah terkulai tidak akan diputuskan-Nya, dan sumbu yang pudar 
nyalanya tidak akan dipadamkan-Nya" (ayat 20) tampak kesan yang sangat kuat bahwa Yesus sang Imanuel sangat peduli bahkan terhadap mereka yang barangkali bagi dunia ini tidak lagi mempunyai harapan untuk lebih baik. Dengan demikian Yesus sang Imanuel - Hamba adalah sosok pribadi yang sangat peduli kepada masalahmasalah manusia. Kesimpulan tersebut senada dengan pernyataan Beaton yang menegaskan, "This study [the quotation of Isa. 42:1-4 in Matt. 2:18-20] has reaffirmed the idea that a central concern of Matthew, ......, is the portrait of compassionate, humble servant of the Lord, who offers healing and renewal to the oppressed, damaged, poor and marginalized" (Beaton, 2002).

\section{Yesus sang Imanuel - Pemberita Kerajaan Allah}

Secara eksplisit, penginjil Matius menegaskan Yesus sang Imanuel sebagai Pemberita Kerajaan Allah dalam Matius 4:23 dan 9:35. Sebagai Pemberita Kerajaan Allah, Margaret Hannan menyebutkan aktivitas Yesus menyentuh hampir semua dimensi kehidupan manusia pada saat itu (dalam konteks-Nya) yang ia ungkapkan dengan istilah multiple dimension (Hannan, 2006). Penyajian potret Yesus semacam itu memuat pesan bagi pembaca bahwa tidak ada masalah manusia yang luput dari perhatian Yesus sang Imanuel Sebagai Pemberita Kerajaan itu. Untuk menggambarkan kemultidimensian potret tersebut, Hannan menyajikan berbagai dimensi yang dia maksud, yakni (Hannan, 2006): Pertama, bahwa kabar baik tentang kerajaan itu berkaitan dengan tindakan pembebasan bagi mereka yang mengalami berbagai penyakit dan terbelenggu setan. Kedua, berkaitan dengan anugerah Allah bagi manusia secara universal menembus sekat-sekat etnis, jender, status sosial, profesi, dll. Ketiga, pemberitaan kerajaan itu juga menuntut harga yang harus dibayar, bisa berupa penolakan dari keluarga, penganiayaan atau bahkan kematian. Keempat, bahwa keanggotaan dalam kerajaan itu adalah anugerah Allah, namun demikian bagi komunitas tersebut juga dituntut tanggungjawab berupa cara hidup yang berkenan kepada Allah. Tanggungjawab itu juga meliputi kemauan untuk memberitakan kerajaan itu kepada semua bangsa. Akhirnya Hannan kembali menegaskan bahwa, kedaulatan Allah yang terlihat dalam proklamasi kerajaan Allah dalam Injil Matius ini merupakan sebuah proses transformasi yang terus-menerus. 


\section{Yesus sang Imanuel Sebagai Pembebas}

Berdasarkan analisis literer yang telah penulis sajikan, maka tampak bahwa Yesus sang Imanuel dengan beberapa atribut yang diberikan penulis Matius sangat erat dengan gagasan pembebasan. Setidaknya kita dapat menarik beberapa garis besar dari sosok Yesus sang Imanuel, yakni:

1. Yesus sang Imanuel merupakan orang Nazaret yang memahami dan merasakan pergumulan penduduk miskin karena ia juga berasal dari tempat yang sama dengan mereka.

2. Yesus sang Imanuel merupakan Hamba yang berbelas kasihan yang menawarkan pemulihan dan pembaharuan bagi orang yang tertindas, hancur, miskin dan termarjinalkan.

3. Yesus sang Imanuel merupakan Pemberita Kerajaan Allah yang memberitakan dan melakukan tindakan pembebasan bagi mereka yang mengalami berbagai penyakit dan terbelenggu setan. Tidak hanya berbagai penyakit dan belenggu setan, tetapi juga menyentuh semua aspek kehidupan manusia - multiple dimension. Artinya tidak ada satu pun permasalahan manusia yang luput dari Yesus sang Imanuel.

Berdasarkan garis besar tersebut, tidak terlalu berlebihan jika dikatakan bahwa gagasan dari masing-masing atribut tersebut mengarah kepada tindakan pembebasan. Yesus sang Imanuel dalam Injil Matius merupakan sosok "pembebas" bagi orang-orang yang termarjinalkan. Tetapi untuk lebih memperkuat kesimpulan tersebut, penulis akan menampilkan konteks historis pembaca pertama Injil Matius. Seperti yang telah disebutkan sebelumnya, Injil Matius merupakan sebuah refleksi dan respons terhadap pembaca pertamanya. Apakah benar pembaca pertama membutuhkan pembebasan seperti yang tampak dari sisi literernya?

\section{Analisis Konteks Historis Komunitas Matius}

Sebagian besar ahli menyimpulkan bahwa Injil Matius dituliskan kepada komunitas Matius di Anthiokia ibukota Siria beberapa tahun setelah perang Yahudi (Sim, 1998). Komunitas Matius adalah orang-orang Yahudi. Walaupun di dalamnya ada orang-orang non-Yahudi, besar kemungkinan mereka telah mengalami proselitasi. Kemudian Injil Matius ditulis setelah kejatuhan Bait Suci dan Yerusalem tahun 70 M atau dapat diperkirakan sekitar tahun 85-95 M (Sim, 1998). Sebagaimana yang dikatakan Sim bahwa, "the important point for our purposes is that Matthew wrote his Gospel after the destruction of Jerusalem" (Sim, 1998). Tahun 85-95 M hanyalah 
prediksi waktu terbaik yang dapat diperkirakan. Dengan demikian komunitas Matius beraktivitas pasca Perang Yahudi (Jewish War) yang terjadi pada tahun 67-70 M yang menyebabkan kehancuran Bait Suci dan Yerusalem pada tahun $70 \mathrm{M}$. Peristiwa tersebut yang sangat mempengaruhi situasi Komunitas Matius.

Pada saat Injil Matius ditulis, Komunitas Matius setidaknya sedang mengalami pertentangan dalam 3 lingkaran, yakni:

1. Pertentangan dengan Induk Yudaisme. Komunitas Matius merupakan salah satu kelompok dalam Yudaisme (Yudaisme Bait Allah Kedua=YBAK). Setelah kehancuran Bait Suci dan Yerusalem, terjadi sebuah kebangkitan dalam tubuh Yudaisme yang sering disebut dengan era Formative Judaism (FJ). Dalam era FJ, Yudaisme berusaha untuk menyelamatkan kembali iman Yahudi. Sebagai konsekuensinya kelompok yang dianggap memiliki ajaran yang menyimpang dari iman Yahudi dikeluarkan dari Yudaisme. Sangat banyak ahli yang berpendapat bahwa Komunitas Matius adalah salah satu sekte di dalam YBAK (Sim, 1998). Sim mengatakan bahwa bagi induk Yudaisme, Komunitas Matius tidak bisa lagi dibiarkan tetapi harus dibasmi (Sim, 1998). Upaya pembasmian sekte dalam Yudaisme pada era FJ juga direkam oleh Donald Senior pada saat mengutip Tiffilah (semacam doa-doa dalam Sinagoge) di Yamnia sekitar tahun 85 M. Adapun isi doa tersebut yakni: “... let Christian and minim (probably meaning 'heretics') perish in a moment, let them be blotted out of the book of the living and let them not be written the righteous" (Senior, 1983). Komunitas Matius muncul dan beraktivitas dalam sebuah situasi pertentangan yang cukup kompleks dan berkepanjangan. Dengan demikian dapat dilihat bahwa Komunitas Matius sedang berada dalam keadaan tertindas akibat upaya pembasmian yang dilakukan oleh induk Yudaisme

2. Pertentangan dengan kelompok Law Free Christian di Antiokhia. Hal ini tidak bisa dilepaskan dari perkembangan Kekristenan mula-mula di Antiokhia. Secara garis besar, Kekristenan mula-mula dapat dibagi menjadi dua warna yakni: aliran Law Observant Christian (yang menekankan pelaksanaan Taurat) yang berpusat di Yerusalem dengan tokohnya Yakobus saudara Yesus; kemudian ada aliran Law Free Christian (tidak terikat dengan pelaksanaan Taurat) yang berkembang di Antiokhia dengan tokohnya Paulus. Komunitas Matius sendiri merupakan aliran LO yang berada di Antiokhia. Pada mulanya, gereja di Antiokhia berwarna LF bahkan Antiokhia menjadi pusat misi LF (Sim, 1998). Hal tersebut tidak terlepas dari pekerjaan Paulus dan Barnabas di Antiokhia. Tetapi gereja Yerusalem di bawah pimpinan Yakobus berusaha agar gereja di Antiokhia berada di bawah kendali 
gereja Yerusalem. Singkat cerita, setelah sidang di Yerusalem (Kis.15) dan pertentangan antara Paulus dengan Petrus (Gal. 2:11-14), Paulus pergi meninggalkan Antiokhia. Dengan kepergian Paulus maka sejak saat itu (sekitar tahun $49 \mathrm{M}$ ), gereja di Antiokhia berubah aliran menjadi LO yang bearada di bawah kendali gereja di Yerusalem. Tetapi perang Yahudi yang berimbas pada kejatuhan Yerusalem dan Bait Suci tahun 70 CE menyebabkan gereja Yerusalem mulai kehilangan kendali di Antiokhia dan aliran LF kembali mendominasi Antiokia (Sim, 1998). Pada saat Injil Matius dituliskan, kelompok LF mendominasi Gereja Antiokhia di mana pada saat itu masih ada pewaris aliran LO yakni Komunitas Matius. Sim menyimpulkan bahwa dominasi LF atas gereja Antiokhia setelah kejatuhan Yerusalem dan Bait Suci memberi tekanan kepada Komunitas Matius yang merupakan aliran LO (Sim, 1998). Dengan demikian Komunitas Matius merupakan kelompok minoritas di Antiokhia yang berada dalam dominasi kelompok LF.

3. Pertentangan dengan orang-orang non-Yahudi secara etnis dan pengaruhnya bagi kehidupan sosial-politik. Telah dijelaskan bahwa Komunitas Matius merupakan kelompok orang Yahudi, meskipun ada beberapa orang non-Yahudi tapi besar kemungkinan sudah mengalami proselitisasi. Sedangkan Antiokhia bukanlah kota orang Yahudi, sehingga Komunitas Matius merupakan kelompok minoritas secara etnis. Selain itu, pada saat itu baru saja terjadi pembantaian besar-besaran terhadap orang Yahudi oleh tentara Romawi pada saat Perang Yahudi. Donald Senior menyebut peristiwa tersebut sebagai holocaust (Senior, 1983). Peristiwa tersebut tentu sangat memengaruhi kehidupan sosial-politik komunitas Matius.

Berdasarkan gambaran tersebut, dapat disimpulkan bahwa komunitas Matius berada dalam situasi krisis yang sangat serius. Tidak hanya mengalami tekanan secara fisik dan traumatik karena peristiwa "holocaust," namun mereka juga mengalami krisis identitas yang sangat serius. Pelita Surbakti dengan meminjam istilah Manuel Castells, menyimpulkan bahwa Komunitas Matius ini berada pada level resistance identity, yakni sebuah krisis identitas kolektif akibat stigmatisasi dari kelompok mayoritas dan dominan (Surbakti, 2017). Dengan demikian penulis menyimpulkan bahwa memang benar bahwa upaya penulis menyajikan Yesus sebagai Imanuel yang dilengkapi dengan atribut lainnya tersebut memiliki gagasan pembebasan. Telah dijelaskan bahwa Komunitas Matius sedang berada dalam kondisi krisis identitas akibat berbagai pertentangan yang dihadapinya. Bukankah Komunitas Matius membutuhkan sosok pembebas bagi mereka yang sedang mengalami kondisi 
krisis identitas? Oleh karena itu sangat logis jika Yesus sang Imanuel merupakan Pembebas bagi komunitas Matius. Dari sisi literer dan konteks historis pembaca pertama Injil Matius jelas terlihat bahwa Yesus Sang Imanuel merupakan sosok Pembebas.

\section{Implikasi bagi Gereja di Indonesia}

Dalam Perjanjian Baru (misalnya Kolose 1:18; Efesus 1:22; dll.), kita menemukan metafora gereja seperti tubuh di mana jemaat adalah tubuh Kristus dan Kristus adalah kepala gereja. Dengan demikian, sudah semestinya gereja mengikuti apa yang telah dilakukan oleh Kristus sang kepala gereja. Berdasarkan penjelasan di atas, Yesus merupakan sosok pembebas. la memahami dan merasakan pergumulan orang miskin dan tertindas sebab la berasal dari tempat yang sama dengan mereka. Oleh sebab itu Yesus menawarkan pemulihan dan pembaharuan - pembebasan bagi orang yang tertindas, hancur, miskin dan termarjinalkan. Fokus Yesus mencakup seluruh aspek kehidupan manusia sehingga tidak ada permasalahan manusia yang luput dari perhatian Yesus. Oleh karena itu sudah semestinya pula gereja-gereja, khususnya di Indonesia, melakukan tindakan "blusukan" untuk memahami dan merasakan pergumulan jemaat. Gereja menaruh perhatian dan melakukan tindakan pembebasan kepada orang-orang yang tertindas, hancur, miskin dan termarjinalkan. Sebab demikianlah yang dilakukan oleh Kristus yang merupakan kepala gereja.

\section{KESIMPULAN}

Setelah melihat sisi literer dan konteks historis pembaca pertama Injil Matius maka terlihat bahwa Injil Matius memuat gagasan pembebasan di dalamnya. Gagasan pembebasan tersebut diwujudkan secara literer melalui sosok Yesus Sang Imanuel yang sangat ditonjolkan dalam Injil Matius. Upaya penulis Matius menyajikan Yesus Sang Imanuel ternyata merupakan sebuah respons terhadap situasi Komunitas Matius yang sedang berada dalam kondisi krisis identitas. Dalam keadaan kondisi krisis identitas tentu saja Komunitas Matius membutuhkan sosok Pembebas yang disajikan oleh penulis Matius melalui sosok Yesus Sang Imanuel. Dengan demikian dapat disimpulkan bahwa gagasan pembebasan yang diusung dalam Teologi Pembebasan memiliki landasan alkitabiah. Hal ini sebagai jawaban terhadap kritikan para ahli yang mengatakan bahwa teologi pembebasan berasal dari penafsiran Alkitab yang tidak benar. Bahkan ada pula yang mengatakan Yesus bukanlah sosok pembebas. Pandangan-pandangan tersebut perlu direspons sebab dapat menutup ruang bagi 
gereja untuk menaruh perhatian dan bertindak terhadap permasalahan sosial dalam masyarakat. Nyatanya, Yesus Sang Imanuel merupakan sosok pembebas yang memahami dan merasakan pergumulan manusia serta menawarkan pembebasan bagi mereka yang tertindas, hancur, miskin dan termarjinalkan. Gereja-gereja juga sudah semestinya mengikuti Kristus sebagai kepala gereja untuk memahami dan merasakan pergumulan manusia serta menawarkan pembebasan bagi mereka yang tertindas, hancur, miskin dan termarjinalkan.

\section{DAFTAR PUSTAKA}

Beaton, R. (2002). Isaiah's Christ in Matthew's Gospel. Cambridge University Press.

Boof, L., \& Boof, C. (1987). Introducing Liberation Theology. Burns \& Oates.

Browning, W. R. F. (2011). Kamus Alkitab (L. K. Yang \& B. Subandrijo (Eds.)). BPK Gunung Mulia.

Carter, W. (2011). Matthew and Empire: Initial Explorations. Trinity Press International.

Elliot, J. H. (1995). Social-Scientific Criticism of the New Testament: An Introdution. SPCK.

Hannan, M. (2006). The Nature and Demands of the Sovereign Rule of God in the Gospel of Matthew. T\&T Clark.

Kupp, D. (1996). Matthew's Emmanuel. Cambridge University Press.

Luz, U. (1995). The Theology of the Gospel of Matthew (J. B. Robinson (Ed.)). Cambridge University Press.

Meleshko, A. (2013). Hermeneutic of the Theology of Liberation: Community and Freedom. Theological Reflection/DCU.

Natalie. (2000). Evaluasi Kritis terhadap Doktrin Gereja Dari Teologi Pembebasan. Veritas, 1(2).

Saldarini, A. (2001). Reading Matthew without Anti-Semitism. In D. E. Aune (Ed.),

The Gospel of Matthew in Current Study. WB Eerdmans.

Segovia, F. F. (2006). Biblical Criticism and Postcolonial Studies. In R. S.

Sugirtharajah (Ed.), The Postcolonial Biblical Reader. Blackwell Publishers.

Senior, D. (1983). What Are They Saying about Matthew. Paulist Press.

Sim, D. C. (1998). The Gospel of Matthew and Christian Judaism. T\&T Clark.

Sugirtharajah, R. S. (2001). The Bible and the Third World: Precolonial, Colonial and Postcolonial Encounter. Cambridge University Press.

Surbakti, P. H. (2017). Yang Terutama dalam Amanat Agung: Sebuah Pencaian 
Makna Kata Tērein dalam Matius 28:20a. BPK Gunung Mulia.

Vogel, Z. (2018). Liberation Theology: A Critical Analysis. Kairos - Evangelical Journal of Theology, XII(1). 